\author{
Jen Webb
}

\title{
Depression and Creative Writing Students
}

The tradition of the oppressed teaches us that the 'state of emergency' in which we live is not the exception but the rule. (Walter Benjamin 257)

\section{Introduction - some small stories}

The phone rings, and it's someone's mother, the mother of a first year student. He's young, engaging, and his writing shows promise. 'What's happening to my son?' she asks me, his program director but not his tutor. Someone (me) who knows him barely at all is being asked this, by the person who (we assume) has known him intimately for eighteen years. 'We - his dad and me - we haven't been able to talk to him. We're worried about him. He's acting...so strange.' And a year later, after failing all his subjects by non-completion, he withdraws from the university.

The phone rings, and it's someone's father, the father of a second year student. She's young, engaging, her writing shows promise, and he is in tears. 'Can you help me?' he asks. 'My daughter is in hospital; she won't be coming back this semester.' We complete and sign off on the late deferral papers, and the following year she resurfaces, medicated and scarred.

There's an assignment due, and in the weeks before and after the due date I get visits and calls and emails from students bearing notes written by their counsellors and psychiatrists; from the Disabilities Office about students frozen by anxiety or depression; from psychologists and social workers on behalf of their clients. Some students email me drafts of work from the psychiatric hospitals to which they retreat every few weeks; others speak to me only in the presence of another professional. Last semester a disturbingly large number of the first year writing students presented with documented depression, anxiety, obsessive-compulsive disorder, bipolar disorder, Asperger syndrome, schizophrenia...and this in a university where only four per cent of students have registered with any form of disability at all. On bad days, it seems as though almost every student in my program is riddled with sorrow, anxiety, and the incapacity to be at home in the world.

The frequent documentation of mental or emotional ill-health happens routinely in my workplace, and possibly in yours too. Our students seem increasingly wretched, and are increasingly armed with notes from their therapist or their doctor. We swap stories of suicide threats and suicide 
attempts, and too many of us know someone who's lost a student, or has found a student's body in the studio or carpark. What is happening in the world that causes engaging, promising, talented young people to find life so insupportable that they can't continue without external support? And is it just writing students, or is it students generally, or is it a feature of society as a whole?

My investigation into these questions is at this stage in the order of what Pierre Bourdieu would call 'spontaneous sociology' (Bourdieu et al 13). That is to say, I haven't yet sought ethical clearance, developed an epistemological framework and research methodology, or interviewed students, parents and caregivers. At this stage all I want to do is flag the issue, and begin to think through the situation. Without a formal research project to underpin my perspective, I don't want to overstate the case for major problems in our student body; after all, students may simply be using the counselling and medical services to ensure extensions to their due dates for work. Still, the fact that so many may be prepared to go through the hoops of registering as distressed in order to snatch another week is interesting, suggesting as it does that they're under pressures I didn't face in my undergraduate days. This, along with the statistics about the levels of depression and suicide in the general population and specifically among writers should, I think, give us pause for thought, if not for panic.

\section{These postmodern times}

One of the more obvious causes of the levels of distress in the general community is the rapidity of social change; certainly it is this that is indicated (or indicted) in much of the popular literature. I don't suggest that change is necessarily bad; personally, I can point to the sweeping away of any number of fixed, fast-frozen relationships, or ancient and venerable ideas and opinions (Marx and Engels 476) that I applaud - witch-burning, for instance, or primogeniture. But even good change brings stress, and the speed of transition is bound to increase distress. And it does: Simon Gottschalk (1997) notes that psychiatrists in the US have identified anxiety disorder as the most common condition there, affecting over twelve per cent of the population. Therapist Lauren Slater writes that depression is 'suffered by one in ten Americans' at some point (Slater 114). There have been steep rises in antidepressant prescriptions and sales in Canada over the last two decades: an increase of 353 per cent against a one per cent annual population rise over the same period (Whiteside 2002); and a 'significant rise' in antidepressant use in Australia, as reported in the November 2000 Medical Journal of Australia. Perhaps diagnostic tools have improved; perhaps social acceptance of psychological illness has widened; perhaps as a society we're more aware of the condition, and more willing to seek treatment; or perhaps people really are more blue than they used to be.

But if so, what might be the cause/s? Baudrillard, writing in Symbolic Exchange and Death, points out that 'Determinacy is dead, indeterminacy holds sway' (Baudrillard 1993a: 7), which suggests one reason for depression the increased levels of uncertainty. Those of us who read our Freud might have anticipated this, remembering his insistence that 'we do not feel comfortable in our present-day civilization' (Freud 1955: 277). Civilisation - contemporary society - for Freud is not much more than 'the struggle between Eros and Death, between the instincts of life and the instincts of destruction' (Freud 1955: 314). The Frankfurt School critical theorists would have agreed with him, arguing as they did that life under capitalism is necessarily suffering and struggle. Many contemporary cultural theorists would agree too; and many would also point an accusing finger at postmodernity - not its art forms or 
theories, but the postmodern episteme, the pervasive sense of uncertainty and multiplicity than drifts under the surface of assurance throughout western culture. Such theorists posit that postmodern individuals, having become conscious of their own fragmented identity, their nation's contingent reality and the particularity of truth, are likely to suffer any number of disorders: neurosis, schizophrenia, depression, uncertainty, paranoia, nihilism and so on. (note 1) As Tod S. Sloan wrote in Radical Psychology, the current social order

erodes the bases for social norms, solidarity, and sense of community, described by Durkheim as anomie. It subjects labor to the deformation Marx catalogued as alienation. Finally, it interferes with socialization processes related to the formation of personal identity and character. (Sloan 1999)

But actually, uncertainty and despair are not new: thinkers and medical practitioners in the sixteenth and seventeenth centuries were already writing about what they called 'melancholia' which, Certeau points out, they associated with a capacity for what we might call creative ideation:

According to seventeenth century conceptions, an individual with melancholic or hypochondriacal madness persistently combines an image (an 'idea' or 'dream' which is in itself neither true nor false) with an affirmative judgment ('I am' the thing I imagine or dream). (Certeau 103)

What we might argue, then, is that depression is a very human state, but has a much more public identity than it once did; and may be more 'medicalised' than in earlier periods (the depressed are no longer considered hypochondrical). Certainly, it may be a necessary effect of the loss of fast-frozen relations (change always causes stress, if not distress). But - and here I start to get more interested - it is also associated with imagining, with creative thought. Freud makes this point too:

We may lay it down that a happy person never phantasies, only an unsatisfied one. The motive forces of phantasies are unsatisfied wishes, and every single phantasy is the fulfilment of a wish, a correction of unsatisfying reality. (Freud 1959a: 146)

But it's more than that: Certeau points out that melancholia isn't just imagining; it also involves reasoning (or judgment) however illogical that reason might appear to be; and it involves investing in myself the product of my imagination ('I am' the thing I imagine or dream). In other words, it is an effect of a disjuncture in what Freud would later call the reality principle, that part of ourselves which is willing to defer the search for pleasure, to postpone satisfaction, for the sake of self-preservation. 'Healthy' people, he writes, understand the difference between phantasy and reality; depressives and other neurotics don't because 'what neurotics are guided by is not ordinary objective reality but psychological reality' (Freud 1959b: 80). Or, according to the seventeenth-century writers whom Certeau cites, when it comes to melancholia, reality is absorbed into phantasy.

\section{Genius and madness: new stories for old}

Creative writers are among those groups of people and practitioners who use their imaginations more, arguably, than do the general public; so is it therefore 
reasonable to assume that writers are more melancholy, more neurotic, than the public at large? Perhaps. Certeau writes:

Fiction is written in the language of a rejected land and a dispossessed body, with all the trappings of a fatal exile or an impossible exodus. Fiction is the solitary machine which engineers the Eros of death. (Certeau 157)

But this does sound a little like that old chestnut about artists suffering in garrets, and by extension the Romantic notion that all genius is attended by madness.

To my surprise, this axiom has some validity. Psychiatrist Kay Redfield Jamison found, in her study of the relationship between affective disorders and creativity, that eighty per cent of the writers she studied suffered at some point from an affective disorder, compared with only thirty per cent in the control group. Felix Post published his own study into mental illness and art, in which he found that half of all writers he studied suffered from clinical depression, compared with only a quarter to a third of the general population. What is particularly noteworthy is that writers are more likely than are other creative practitioners to suffer from mood disorders; and poets and novelist more likely than anyone else to suffer from what he terms 'severely deviant personality traits':

The cluster of traits, which might be called schizoform because it often precedes schizophrenia, was rarely schizoid or paranoid-fanatic in type (mainly found in various dictators), but more often schizotypal: vague in manner of talking, neglectful in dress and personal hygiene, regarded as odd by others, and sometimes subject to trance-like states and paranormal experiences. (Post 2001)

The most common characteristics he identified were anxiety, depression and some obsessional tendencies. Post sums up by noting that artists are no more likely than the general population to be insane or neurotic, but that poets, novelists and playwrights are more anxious, depressed and manic-depressive than everyone else.

Perhaps these data reflect the fact that writers are skilled with words, and so can articulate their sorrows and anxieties in a way that painters and scientists cannot. Certainly contemporary writers have written endlessly about their own sorrows and despairs, sometimes through a narrator, sometimes in the first person (we might think of William Styron, or Sylvia Plath, or Elizabeth Wurtzel, among many others). All the same, the validity of the measuring tools of psychiatry is well established, and the statistics associated with rates of suicides and suicide attempts bear out Post's findings. The rates among writers - specifically poets and novelists - are significantly higher than those in the general population (between six and eighteen times higher than the general population, across a number of surveys) which points to more than fluency being reflected here.

Post's and Jamison's researches were conducted and published in the past few years, but the story they tell of the connection between depression and creative practice is an old one. The sixteenth century writer Romano Alberti wrote that:

Painters become melancholics because, wishing to imitate, they must retain the phantasms fixed in the intellect, so that afterward they can express them in the way they first saw them when present. ...They keep their minds so much abstracted and 
separated from nature that consequently melancholy derives from it. (Romano Alberti, cited in Agamben 25)

Writers, we might argue, do the same work of abstraction in order to make creative representations, and so derive the same degree of melancholy. It is important to distinguish between melancholy, and more temporary suffering, and here we can turn again to Sigmund Freud, and specifically his lovely essay 'Mourning and Melancholia' (Freud 1959c). He writes that these two conditions share the same cause - loss - and that they have similar effects: each removes the person from normal everyday life and attitudes, and each involves in the sufferer an exclusive devotion to that which was lost. But they differ too - we regard mourning as natural and necessary, something time will remedy, but we treat melancholia as having a pathological quality. And mourning is always associated with a recognisable, identifiable loss of a loved person or object, while melancholia is often associated with a loss that can't be identified.

Perhaps the most important difference between mourning and melancholia, for Freud, is that mourning is involved with reality principle. The bereaved 'normal' person realises that 'the loved object no longer exists, and it proceeds to demand that all libido shall be withdrawn from its attachments to that object' (Freud 1959c: 244). This is hard work; it takes active investment because, as Certeau writes, forgetting 'is not something passive, a loss, but an action directed against the past' (Certeau 3). A 'normal' person will understand the process, move through this work of separation, and come out the other side reintegrated and healthy.

The melancholic's experience is very different, partly because the loss being grieved rarely obeys the reality principle. Freud provides the example of the internalised loss associated with being jilted (Freud 1959c: 245). The person grieving knows who, but not what, has been lost - the lover has gone, but what I have really lost is not him/her, but the idea(l) of myself as desirable, as someone who is loved. I can't afford to think about this, so the true loss, ego loss, remains in the realm of the unconscious, and not available for the work that is mourning. I may withdraw love from the lost person, as is the case in mourning, but unlike the mourner I won't end up with a free ego. Instead, the libidinal energy that I withdraw from my untrue lover retreats into and becomes associated with the ego. Now the true loss I experience, or internalise, is not my lover, but my self-worth (Freud 1959c: 249) - and not a reality, but a phantasm; in this case, the phantasy of happily-ever-after.

But if it is the case that melancholy, or depression, is the effect of an unconscious loss that generates the loss of self-esteem, what could be the cause of the higher-than-average depression among writers? What have we lost, and internalised, that is shadowing our own egos? I wouldn't dream of saying It's this! It's that! as though there were a single and a consistent cause. Almost certainly, the causes are myriad and varied. But I would like to suggest some socio-economic effects that may be driving this, and that may be distressing the students in writing programs around Australia.

\section{'It's the economy, stupid!'}

The effect is associated with the climate produced by various conservative governments, under whose leadership - researchers are finding - depression levels rise. By 'conservative' here we mean committed to free market capitalism, governments who believe in and invest in the market rather than the community; governments who exile social capital in favour of big business, international conglomerates, the bottom line, the level playing field. These 
findings shouldn't really surprise us. Durkheim, back in the nineteenth century, had already noticed the association of higher suicide with times of economic boom and bust. But in times of boom or bust, it's the economy (as Bill Clinton pointed out) that gets all the attention, while the society and its norms are relegated to a back burner.

As are the people who live within that society, and mobilise the norms. Courtney Campbell wrote, alarmingly, of having been at a medical school in the United States where she was told that under the economic imperative which insists that hospitals and medical centres operate as competitive economic units, not places of healing, patients are no longer seen as people. Doctors, she was told by a medical practitioner, were 'now referring to patients as "IPBUs", which stands for Income Producing Biological Units'. Mmmm. Sign me up to be operated on by one of those doctors, please! These sorts of effects across the board are necessary outcomes of unrestricted capitalism, of an unqualified privileging of 'the free flow of capital, commodities, and resources' (Mattelart \& Mattelart 156-57) that locates human beings as resources, not as people. But 'free flow', they go on to note, 'is like a free fox among free chickens' (Mattelart $\&$ Mattelart 157); and students in particular are like free chickens among the free foxes of the socio-economic system. Their social needs aren't valued; they aren't eligible for financial support unless their parents are terribly impoverished, or they themselves are over twenty-five; if they do manage to swing Austudy payments, the levels they receive are insufficient to support life. So they need to work at one or several part-time jobs while juggling study while learning how to be a university student while, very often, entering their first very serious romantic relationships and often while coming to terms with having left their family home - while at the same time being aware they are running up a very large HECS debt. There's nothing complexly psychoanalytical about this, just basic economics.

But for writing students there's something more going on. Students in engineering and law know the odds are that they'll go into well-paid jobs, because they are preparing themselves for a career within the capitalist system. They can, therefore, operate according to Freud's reality principle, and defer pleasure in the interests of overall long-term benefits. Writers don't have this reality principle. They are deferring pleasure in the interests of... deferring pleasure to... maybe write a book of poems that might if they're lucky be published in a run of 300 of which they'll buy 40 and another 150 will be remaindered. But hey, who's counting? After all, we're not in it for the money. And yet, we are. As members of this community, as individuals invested in the social contract, we are interpellated by capitalist logic, caught up in its necessarily boundless and insatiable appetite, and are workers for the creation of surplus value. But as creative writers, as producers of poems and novels, this is something we rarely achieve. Few writers make any serious money out of their writing. And even if they do: capitalism is based on the notion that surplus value is created when the value of production exceeds labour and other associated costs. Those costs, for any creative practitioners, include all of $m e$. How do we quantify that, or determine when the value of production exceeds that all of me cost?

But wait, there's more: capitalism isn't just about making a buck. It's also, arguably, about salvation - or being safe in the world. Baudrillard writes that the sixteenth-century counter-Reformation:

gave rise to the immense modern enterprise of staving off death: the ethics of accumulation and material production, sacralisation through investment, the labour and profit collectively called the "spirit of capitalism" [Weber] 
collectively constructed a salvation-machine from which intraworldly ascesis is little by little withdrawn in the interests of worldly and productive accumulation, without changing the aim of protecting itself against death. (Baudrillard 1993a: 14546)

The person who dies with the most stuff, wins. Writers know that the accumulation of stuff is not going to be easy, and besides is not valued in our part of the social field; but without that, how can we stave off death, or feel safe? What I suggest is internalised in this scenario, according to Freud's notion of melancholy, is the very principle of safety. It is the loss of an ideal, an abstraction, one that can't easily be recovered unless we decide to go the potboiler or commercial way, in which case we exchange the melancholy over accumulation for the melancholy likely to be associated with the loss of the idea of myself as autonomous writer - a damned if you do, damned if you don't situation.

\section{And then there's the media}

A related issue that affects writers in this period of capitalist hegemony is the effect of the media on the world in which we live and in which we make our works; a world which, as I noted earlier, is postmodern. One of the central features of postmodern organisation is the privileging of what Manual Castells calls informationalism (that is, the pre-eminence of knowledge, information and communication). Castells argues that informationalism associated with the new communication technologies has had a pervasive and irreversible impact upon the way we understand time and space, which in turn has transformed all the main spheres of human activity - economic, cultural, social and political. This has the potential to affect writers and writing of creative works most profoundly. Little of what we do in a novel or collection of poems can be said to have an immediate instrumental or communicative utility; it is more likely to be reflective, possibly self-referential, and committed to language and story rather than to information, knowledge or practical communication.

The media system is central to the economic machine because it is the place where everything is exchangeable; it is the point of connection and more - of commutation. But what happens in the media is, very often, the evacuation of the social and the human. This is, we might argue, central to capitalist organisation of society. Just as it can get to the stage where doctors see us as Income Producing Biological Units, so too under capitalism it is important that exchange - by which I mean making more than we spend, getting more than we give - is predicated on a kind of violence, the elision of the common humanity of the person with whom we are exchanging. Brian Massumi picks up on this notion, and refers to the media affect as 'fear-blur'. As the agora, the public sphere face of the capitalist machine, the mass media makes visible to us 'the direct collective perception of the contemporary condition of possibility of being human: the capitalized accident-form' - or, we might add, the IPBU-ism of us all.

And that leads to a further reason for writerly depression. Not only do we find ourselves on the back foot in terms of the social value of our work and our identity as humans rather than income-producers; we also find our role as storytellers and (in Doris Lessing's term) 'memories' (note 2) obviated by the pre-eminence of informational values and the media through which they are promulgated. What we experience, in other words, is the theft of the commons that is our stories. The story of $u s$ in the here and now has been hijacked by 
someone else's fantasy of the 1950s; the story of us here and now as generous, relaxed and multicultural has been hijacked by the new story of us as jailers of asylum seekers; the story of us as egalitarian and larrikin has been hijacked by the story of us as the cheer-squad for big business. And when it comes to the making of stories-as-such - works of the imagination - the dream material we weave into stories has been to a great extent swamped by fragments from the media. Listen to Triple J's morning show, and try to identify banter that doesn't bounce off television referents; or have your first year students do improvisational group work, and see how far they can get if references to Buffy the Vampire Slayer and the Simpsons are banned. This is a theft of the commons which isn't economic, but is rather about the work of creative writers in specific terms, and the understanding of ourselves in general terms.

\section{And how about the community?}

Given these arguments about some of the ways in which writers don't entirely fit into the logic of contemporary society, there is a risk we could lose connection with our community which is likely, in Freud's terms, to cast a shadow on us. This is not a new thought (though one worth the recollection): Spinoza in his Ethics identifies the ability to affect others, and be affected by them as central to pleasure and self-identity. But consistent connection is not part of most writers' lives. Certainly I've had the experience, and have read in any number of writers' diaries, of the cyclic going from connection to no connection, in this pattern:

Good Time: writing well, hanging out with friends

More time with friends, less time writing

Start getting stressed, start to withdraw from friends

Bad Time: don't see friends, no writing

Begin to write about how awful everything is

Writing starts going well, begin to cheer up a bit

Start tentatively easing out into the community

Good Time: writing well, hanging out with friends...

Community is important to our well being and hence to our sense of self. But it takes us away from our writing - that which embodies our sense of self. Whichever choice we make - to write or to be social - we lose the alternative, and for this loss we will suffer melancholy.

\section{And in conclusion}

In a world marked by the absence of referents, where meaning and exchange can have no finality, and where what Baudrillard calls the 'brothel of exchange' - the mass media and its deeply limited number of stories - is the agora, perhaps it's not surprising that people are getting sad. Because it's not just writers, though we are evidently more susceptible than is the general population to melancholy. Everyone is more depressed under conservative governments. This is what Marx might have said, it's what Deleuze effectively did say, and it's what has now been published as the outcome of research in Australia and the UK: suicide rates soar when the government doesn't seem to care, and when the balance of payments counts for more than the welfare of the community. This affects us as teachers, especially as teachers of creative writing, because these data and research findings suggest our students are increasingly at risk. What can we do about it? 
Baudrillard writes: 'We are at the dead end of a fin de siecle so mesmerized by the horror of the century's origins that forgetting is an impossibility for it, and the only way out is denial (1993b: 92). And perhaps we can deal with it all by denying the existence of the things that depress us, by staying in our garrets and lecture halls, by writing our poems. But denial and forgetting are rarely successful, because they will only work when we can go through the cathexis that is mourning, that which results in a true separation from, and hence a forgetting of, what went before. But this is not an easy thing to do, particularly when, as noted, the economy, the media and the community are relatively offlimits to us. But I'd hate to get all the way through this material on depression and suicide and end up by saying There's no hope! We're all gonna die! Of course there are alternatives: that's after all a lynchpin of the postmodern understanding. One is to pay more attention to mental health, which is something we are urged in public service TV bulletins to do. Another is to agitate for socio-economic change - a probably unrewarding approach, and one that is likely to take us far away from our central function, writing. A third is to comfort ourselves by the fact that though we are relatively excluded from the world of economic capital, we are nonetheless able to acquire and use cultural and symbolic forms of capital (see Bourdieu 1990: 118; Bourdieu 1993: 75): the distinction associated with being a recognised cultural practitioner, which can translate into a public identity and voice with which to articulate our demand for a kinder world.

But perhaps the most significant, and certainly the most accessible alternative is also one of the writer's central assets: the imagination. Though writers might be more prone than others to depression, we also have the escape hatch of the phantasy world we can create: 'every single phantasy,' Freud wrote, 'is the fulfilment of a wish, a correction of unsatisfying reality' (Freud 1959a: 146). So one effective way of dealing with depression is to focus on the making of our creative works, and through this to promulgate other stories about the community, society and value that will allow these works to work for us. There's a precedent of sorts for this: Deleuze and Guattari write: 'A child in the dark, gripped with fear, comforts himself by singing under his breath. Lost, he takes shelter, or orients himself with his little song as best he can' (Deleuze \& Guattari 311). This metaphor, their capital-R Refrain, includes what they call 'tales' (Deleuze \& Guattari 312), which makes it apposite for us as writers; and the point of Refrain is to make order.

The 'refrain' may be the thread that carries you out of chaos to the beginning of order; it may be the work of constructing a wall to keep the chaos outside; or it may be the line that allows you to re-enter the world. But it is always a way of making a 'territory', of controlling the environment in which you find yourself (or seeking to control it, or convince yourself that you control it). Territory, for Deleuze and Guattari, is all about style, rhythm, landscapes, expressive qualities, motifs... the tools we deploy as writers to craft our works of imagination. So with luck, and work, perhaps we writers can find our way through depression by crafting our own territory, a place of safety in the midst of chaos, a place from which we can emerge into, and participate in, the wider community.

\section{References}

Agamben, Giorgio 1993 Stanzas: Word and Phantasm in Western Culture (translated by Ronald L. Martinez) University of Minnesota Press, Minneapolis Return to article 
Baudrillard, Jean 1993a Symbolic Exchange and Death (translated by Iain Hamilton Grant) Sage, London Return to article

Baudrillard, Jean 1993b The Transparency of Evil: Essays on Extreme Phenomena (translated by James Benedict) London \& New York, Verso Return to article

Benjamin, Walter 1968 Illuminations (edited with an introduction by Hannah Arendt, translated by Harry Zohn) Fontana, London Return to article

Bourdieu, Pierre 1993 The Field of Cultural Production: essays on art and literature (edited and introduced by Randal Johnson) Polity, Cambridge Return to article

Bourdieu, Pierre 1990 The Logic of Practice (translated by Richard Nice) Stanford UP, Stanford Return to article

Bourdieu, Pierre with Jean-Claude Chamboredon and Jean-Claude Passeron 1991 The Craft of Sociology: Epistemological Preliminaries (edited by Beate Krais, translated by R. Nice) Walter de Guyter, New York Return to article

Campbell, Courtney 1997 Brave New World: Soma, Shakespeare, and Suicide: The Terrors of Techno Utopia http://www.orst.edu/Dept/philosophy/club/utopia/utopianvisions/courtney1.html accessed 23 October 2002 Return to article

Castells, Manuel 1997 The Power of Identity Blackwell, Malden, Mass. Return to article

Certeau, Michel de 1986 Heterologies: Discourse on the Other (translated by Brian Massumi, foreword by Wlad Godzich) U Minnesota Press, Minneapolis Return to article

Deleuze, Gilles and Félix Guattari 1987 A Thousand Plateaus: Capitalism and Schizophrenia (translated by Brian Massumi) U Minnesota Press, Minneapolis \& London Return to article

Freud Sigmund 1959a 'Creative Writers and Daydreaming' The Complete Psychological Works of Sigmund Freud Vol IX, Hogarth Press, London, 141-53 Return to article

Freud Sigmund 1959b 'Group Psychology and the Analysis of the Ego' The Complete Psychological Works of Sigmund Freud Vol XVIII, Hogarth Press, London, 67-143 Return to article

Freud Sigmund 1959c 'Mourning and Melancholia' The Complete Psychological Works of Sigmund Freud Vol XIV, Hogarth Press, London, 237-60 Return to article

Freud Sigmund 1955/1930 'Civilization and Its Discontents' Civilization, Society and Religion: Pelican Freud Library Vol 12, Penguin, Harmondsworth, 251-340 Return to article

Gottschalk, Simon 1997 'The Pains of Everyday Life: Between the DSM and the Postmodern' Studies in Symbolic Interaction 21: 115-146 Return to article

Jamison, Kay Redfield 1994 Touched with Fire: Manic-depressive Illness and the Artistic Temperament Free Press, New York Return to article

Lefort, Claude 1986 The Political Forms of Modern Society: Bureaucracy, Democracy, Totalitarianism (edited by John B Thompson) MIT Press, Cambridge, Mass.

Marx, Karl and Friedrich Engels 1967 The Communist Manifesto Penguin, Harmondsworth Return to article

Massumi, Brian 1993 The Politics of Everyday Fear: EVERYWHERE YOU WANT TO BE http://www.anu.edu.au/HRC/first_and_last/works/feareverywhere.htm accessed 24 October 2002 Return to article

Mattelart, Armand \& Michele Mattelart 1992 Rethinking Media Theory: Signposts and New Directions (translated by James A. Cohen \& Marina Urquidi) U Minnesota Press, Minneapolis Return to article 
Post, Felix 2001 'Every Family in the Land' in A H Crisp (ed) Every Family in the Land: Understanding Prejudice and Discrimination against People with Mental Illness

http://www.stigma.org/everyfamily/fpost.html; accessed 23 September 2002 Return to article

Slater, Lauren 1996 Welcome to my Country: A Therapist's Memoir of Madness Anchor, New York Return to article

Sloan, Tod S. 'The Colonization of the Lifeworld and the Destruction of Meaning' Radical Psychology 1, 2 (Fall 1999) http://www.radpsynet.org/journal/vol1-2/Sloan.html accessed 24 October 2002 Return to article

Spinoza, Benedictus de 1977 Ethics (translated by A Boyle) Heron Books, London Return to article

Whiteside, Jessica 15 Oct 2002 http:/www.newsandevents.utoronto.ca/bin3/021015b.asp, University of Toronto News, accessed 28 September 2002 Return to article

\section{Endnotes}

1. The terms used by such theorists often don't bear much resemblance to definitions favoured by the DSM - the Diagnostic and Statistical Manual of the American Psychiatric Association. Return to article

2. See her Mara and Dann: An Adventure Flamingo (HarperCollins) 1999. Return to article

\section{Notes and Debate}

Moya Costello 'Irrigorous Uncertainties': Writing, Politics and Pedagogy

Dr Jen Webb is Program Director, Professional Writing, in the School of Creative Communication and Culture Studies at the University of Canberra. She also edits the Newsletter for the Australian Association of Writing Programs.

\section{TEXT}

Vol 7 No 1 April 2003

http://www.griffith.edu.au/school/art/text/

Editors: Nigel Krauth \& Tess Brady

Text@griffith.edu.au 